\title{
Probing cations recognized by a crown ether with the 3D-RISM theory. II. 18-crown-6 ether
}

\author{
Y.Maruyama ${ }^{1}$, M.Matsugami $^{2}$, Y.lkuta $^{1}$ \\ 1 Department of Theoretical Studies, Institute for Molecular Science, Okazaki, Aichi, 444-8585, Japan \\ 2 Chemistry, General Education, Kumamoto National College of Technology, 2659-2, Suya, Koshi, Kumamoto, \\ 861-1102, Japan
}

Received June 4, 2007, in final form July 18, 2007

In the previous study, we investigated the cation recognition by 12-crown-4 ether with the 3D-RISM theory [lkuta, Y. et al., Chem. Phys. Lett., 2007, 433, 403], and showed the applicability of the theory to the problem. The results show that a 12-crown-4 ether recognizes $\mathrm{Li}^{+}$and $\mathrm{Mg}^{2+}$. 18-crown-6 ether is widely used in comparison with 12-crown-4 ether. In this study, we calculated three-dimensional distributions of water as well as cations $\left(\mathrm{Li}^{+}, \mathrm{K}^{+}, \mathrm{Mg}^{2+}, \mathrm{Ca}^{2+}\right)$ inside and outside 18-crown- 6 ether in aqueous solutions of electrolytes. A 18-crown-6 ether recognizes not only $\mathrm{Li}^{+}$and $\mathrm{Mg}^{2+}$ but also $\mathrm{K}^{+}$and $\mathrm{Ca}^{2+} . \mathrm{K}^{+}$is dehydrated in the host cavity whereas other cations are hydrated. It is found that a hydration structure, as well as cation size, is important for the molecular recognition by crown ether.

Key words: 3D-RISM theory, molecular recognition, crown ether, cation

PACS: $02.30 . R z, 31.15 . B s, 61.25 . E m$

\section{Introduction}

Several types of molecular recognitions occurring in our body play an essential role in life sustaining. For example, the hemoglobin which is contained in aemia carries the oxygen molecules to the proper cells. Investigation of such a recognition process (mechanism) is an extremely essential issue in understanding the functions of biomolecules in a living system. We have little knowledge of such a process in detail, in spite of strenuous efforts on scrutinizing the recognition process. The interaction between a host molecule and guest molecules is so complicated that it is not easy for both experimental and theoretical studies to reach a straightforward solution with existing methods. Here we propose that we reexamine small system, many aspects of which are well known because some obscurity remains even in the origin of the recognition between crown ethers and metal cations.

Since Pedersen has accidentally discovered the crown ethers, the supra-molecule has attracted many chemists [1-5]. They have carried out numerous investigations of special nature known as one of host-guest molecular recognitions. At present, crown ether is indispensable for the experiments in organic and analytical chemistry, since it plays a role of removing unnecessary metal cations through the experiments. In other words, the wonderful nature of the crown ether is its capability of recognizing metal cations. For instance, 12-crown- 4 recognizes a lithium ion, while it does not recognize a potassium ion. Furthermore, it is empirically known that 18-crown-6 recognizes potassium ion selectivity under lithium ion and potassium ion coexistence. 18-crown-6 is highly flexible and can take many conformations in aqueous solution. In particular 18-crown-6 shows the two typical conformations: known as $C_{i}$ and $D_{3 \mathrm{~d}}$. It is clear that the $C_{i}$ conformation, which forms intramolecular hydrogen bonds, is not capable of trapping a cation, because the cavity of the ether ring is too small to recognize the cation. On the other hand, the $D_{3 \mathrm{~d}}$ conformation can trap a metal cation since its cavity is large enough to recognize and to capture an ion: the shape of the cavity is regarded as a hole. Taking into account the experimental results of this recognition that several metal cations are trapped by the 18 -crown- 6 , it is found that all we have to study is related 
to the $D_{3 \mathrm{~d}}$ conformation for our purpose [6]. We have developed a methodology based on the three dimensional reference interaction site model (3D-RISM) theory, which is a statistical mechanics theory of liquids [8]. The theory succeeded in probing water molecules trapped in a cavity of the hen egg-white lysozyme [9]. It has also been successfully applied to the selective ion binding by the mutants of human lysozyme to reproduce the experimental results [10]. Furthermore, we reported that $3 \mathrm{D}$ distributions of water as well as cations $\left(\mathrm{Li}^{+}, \mathrm{K}^{+}, \mathrm{Mg}^{2+}\right.$ and $\left.\mathrm{Ca}^{2+}\right)$ inside and outside a crown ether (12-crown-6) in aqueous solutions of electrolytes were calculated by means of the 3D-RISM theory. The results showed conspicuous peak inside the host cavity in the case of $\mathrm{Li}^{+}$ and $\mathrm{Mg}^{2+}$, indicating that the cations are recognized by the 12 -crown- 6 . In the case of $\mathrm{Li}^{+}$and $\mathrm{Mg}^{2+}$, the sizes of ions are small enough to fit into the cavity, where the effects of core repulsion are insignificant. In the case of $\mathrm{K}^{+}$, the core repulsion between the cation and the cyclic ether is simply dominant over the other factors, so that it cannot be accommodated in the host cavity. On the contrary, the stabilization due to the chelation is largely compensated by the core repulsion in the case of $\mathrm{Ca}^{2+}$, and it is not enough to pay for the cost of dehydration penalties [11].

In this study, we examined an 18-crown-6 ether in $\mathrm{LiCl}, \mathrm{KCl}, \mathrm{MgCl}_{2}$ and $\mathrm{CaCl}_{2} 0.1 \mathrm{M}$ aqueous solutions. There were earlier contributions concerning a crown ether in water using the ordinary 1D-RISM method [12,13]. One of the papers has actually dealt with 18-crown-6 [13]. Although the system was not seriously affected by the notorious problem of the ergodic trap, they still had to search around the free energy surface of the host-guest complex, using the combined RISM and Monte Carlo procedure, which was proposed earlier by Kinoshita et al. [14]. However, the method is somewhat time consuming, especially when more than two components, say water and ions, are considered as ligands. On the contrary, for our purpose, it is enough to employ the present method (see the next section), which provides a picture of host-guest complexation, in a manner similar to an electron-density map obtained from the X-ray diffraction measurement.

\section{Method}

In our procedure, the solute-solvent correlation functions are obtained from the 3D-RISM theory [8], which is an integral equation theory based on statistical mechanics to obtain the correlation functions from the intermolecular potential functions and the thermodynamics conditions such as temperature and density. The theoretical procedure consists of two steps. The first step is to calculate the density pair correlation function in the electrolyte solutions based on the onedimensional RISM theory, which represent the microscopic structure of distribution of the solvent molecules. In the second step, we immerse a crown ether (18-crown-6) into the solvent, and calculate the 3D distribution of solvent atoms $(\mathrm{O}, \mathrm{H}$, cation and anion) around as well as inside the supramolecule by means of the 3D-RISM theory. In the following, we provide just an outline of the 3D-RISM method.

The 3D-RISM integral equation for the 3D solute-solvent site total and direct correlation functions, $h_{\gamma}^{u v}(\mathbf{r})$ and $c_{\gamma}^{u v}(\mathbf{r})$, is written as [15-18]

$$
h_{\gamma}^{u v}(\mathbf{r})=\sum_{\gamma^{\prime}} c_{\gamma^{\prime}}^{u v}(\mathbf{r}) *\left(\omega_{\gamma^{\prime} \gamma}^{v v}(r)+\rho^{v} h_{\gamma^{\prime} \gamma}^{v v}(r)\right)
$$

where $\omega_{\gamma^{\prime} \gamma}^{v v}(r)=\delta\left(r-l_{\gamma^{\prime} \gamma}^{v v}\right)$ is the intramolecular matrix of solvent molecules with site separations $l_{\gamma^{\prime} \gamma}^{v v}, \gamma$ and $\gamma^{\prime}$ are interaction sites of solvent molecules denoted with superscripts " $u$ " and " $v$ ", respectively, $\rho^{v}$ is the solvent number density and ${ }^{*}$ denotes convolution in direct space. The radial site-site correlation functions of pure solvent, $h_{\gamma^{\prime} \gamma}^{v v}(r)$, are obtained independently of the conventional 1D-RISM theory modified with the dielectrically consistent bridge corrections of Perkyns and Pettitt [19,20]. It provides a proper description of the dielectric properties of solution. In the 3D-RISM context, this ensures a proper macroscopic dielectric constant of solvent around the solute $[18,21]$. The $3 \mathrm{D}$ solute-solvent site correlation functions are specified on a $3 \mathrm{D}$ linear grid in a rectangular supercell, and the convolutions in (1) are handled by means of the 3D fast Fourier transform. 
We have recently proposed and tested the new closure which will be referred to as the KovalenkoHirata approximation $[17,18,21,22]$. In the 3D case, however, it should include corrections for the supercell periodicity artifact to both the direct and total 3D site correlation functions, $c_{\gamma}^{u v}(\mathbf{r})$ and $h_{\gamma}^{u v}(\mathbf{r})$, which become essentially important for a solute carrying charges. The closure thus takes the form $[17,23]$

$$
\begin{aligned}
& g_{\gamma}^{u v}(\mathbf{r})=\left\{\begin{array}{cll}
\exp (\chi)+\Delta Q_{\gamma}^{u v} & \text { for } & \chi \leqslant 0 \\
1+\chi+\Delta Q_{\gamma}^{u v} & \text { for } & \chi>0
\end{array}\right. \\
& \chi=-\beta u_{\gamma}^{u v}(\mathbf{r})+h_{\gamma}^{u v}(\mathbf{r})-c_{\gamma}^{u v}(\mathbf{r})-\Delta Q_{\gamma}^{u v},
\end{aligned}
$$

where $g_{\gamma}^{u v}(\mathbf{r})=h_{\gamma}^{u v}(\mathbf{r})+1$ is the $3 \mathrm{D}$ solute-solvent site distribution function, $\beta=1 /\left(k_{\mathrm{B}} T\right)$, the interaction potential $u_{\gamma}^{u v}(\mathbf{r})$ between solvent site $\gamma$ and the whole solute is calculated on the supercell grid using the Ewald summation method, and

$$
\Delta Q_{\gamma}^{u v}=\frac{4 \pi \beta}{V_{\text {cell }}} q_{0} \lim _{k \rightarrow 0} \sum_{\gamma^{\prime}} \frac{q_{\alpha}}{k^{2}}\left(\omega_{\gamma^{\prime} \gamma}^{v v}(k)+\rho^{v} h_{\gamma^{\prime} \gamma}^{v v}(k)\right)
$$

is the shift in the distribution functions due to the supercell background for the solute with net charge $q_{0}=\Sigma_{\alpha} q_{\alpha}^{u}$ comprising the partial site charges $q_{\alpha}^{u}$. The $3 \mathrm{D}$ solute-solvent site direct correlation functions $c_{\gamma}^{u v}(\mathbf{r})$ calculated from the 3D-RISM equation (1) with the closure (2) must be corrected by subtracting the long-range electrostatic asymptotic of the periodic potential $u_{\gamma}^{u v}(\mathbf{r})$ synthesized by the Ewald summation, and adding back that of the single, non-periodic solute simply tabulated on the 3D grid within the supercell $[18,21]$.

For the pair potentials between interaction sites of every species, we employ the common model which consists of the Lennard-Jones (LJ) and electrostatic interaction terms

$$
u_{\alpha \gamma}(r)=4 \epsilon_{\alpha \gamma}\left[\left(\frac{\sigma_{\alpha \gamma}}{r}\right)^{12}-\left(\frac{\sigma_{\alpha \gamma}}{r}\right)^{6}\right]+\frac{q_{\alpha} q_{\gamma}}{r},
$$

where $q_{\alpha}$ is the partial charge on site $\alpha$, and $\epsilon_{\alpha \gamma}$ and $\sigma_{\alpha \gamma}$ are the LJ energy and size parameters for a pair of sites $\alpha$ and $\gamma$, respectively. For the crown ether and ions, we employ the parameters from the OPLS force field [24,25]. We use the SPC/E model [26] with the hydrogen Lennard-Jones term $(\sigma=0.4 \AA$ and $\epsilon=192.5 \mathrm{~J} / \mathrm{mol})$ for the water sites. Calculations are carried out for aqueous solutions at $298.15 \mathrm{~K}$. These parameters and the thermodynamic conditions of solvents are the same as those in the previous study [11].

The molecular structures of the crown ether are optimized in vacuo at B3LYP/6-31G(d) level using Gaussian 03 [7]. We used $D_{3 \mathrm{~d}}$ conformation of 18 -crown-6 in this study. The 3D-RISM/KH equations were solved on a grid of $128^{3}$ points in a cubic supercell of size $64 \AA^{3}$. The supercell is sufficiently large to hold a crown ether with enough solvation space. The grid space of $0.5 \AA$ is fine enough to avoid significant numerical errors. For better convergence of the equations, we used the modified direct inversion in the iterative subspace (MDIIS) method [27].

\section{Results and discussions}

First, we examine whether an 18-crown-6 ether can recognize an ion or not by using the 3DRISM theory. The 3D distribution functions (3D-DFs), $g(\mathbf{r})$ which are obtained by the 3D-RISM theory, are very useful and appropriate for answering this question. If $g(\mathbf{r})$ inside the host molecule is greater than unity, which is the case in the bulk solution, it indicates that "the host molecule recognizes the guest one". Through the present article, we employ the isosurface representation to show $3 \mathrm{D}$ distributions $g(\mathbf{r})$ of water and/or the cations, calculated with the 3D-RISM theory: the region where $g(\mathbf{r})$ is greater than a threshold value is shown by color for each species of solvent. Figure 1 shows the $g(\mathbf{r})$ for (a) water oxygen colored with light blue and (b) water hydrogen colored with white around 18-crown- 6 in pure water. The threshold value of $g(\mathbf{r})$ are 2,4 and 8 from the left to the right, respectively. For example, $g(\mathbf{r})=2$ means that the corresponding site 
is distributed twice as probable as in the bulk phase. These results give us some information that the spots inside the crown ether are not only small but also conspicuous. The right figures in (a) and (b), of which thresholds are $g(\mathbf{r})=8$, indicate that the supramolecule does recognize water molecules: that is, the cavity is not empty when the host molecule exists even in pure water. This result is not surprise if one compares the size of a water molecule (about $2.8 \AA$ ) with the cavity diameter (about $5.8 \AA$ ).

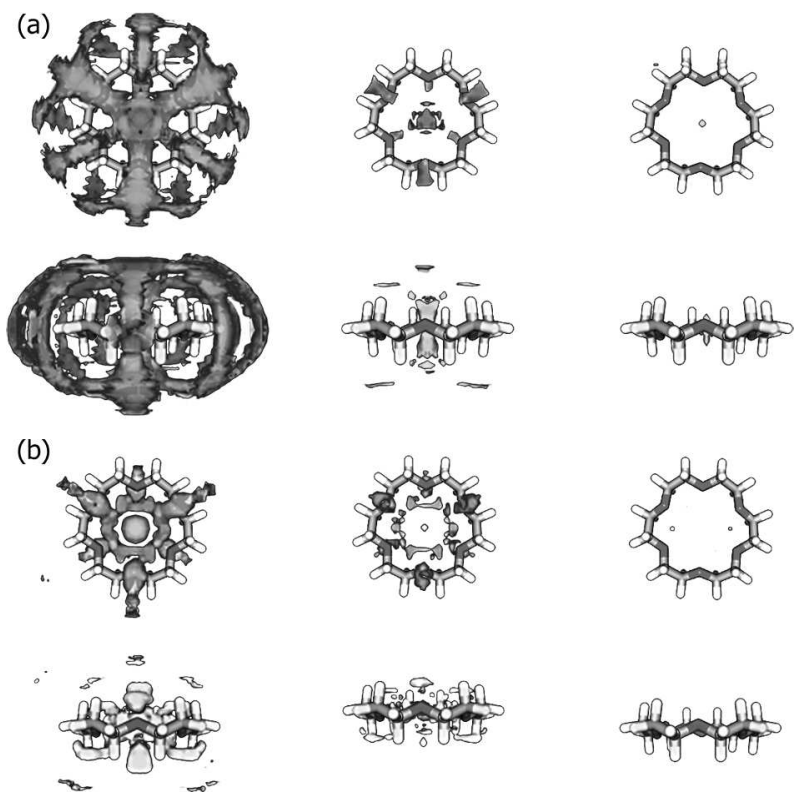

Figure 1. Isosurface representation of the three-dimensional distribution function of water (a) oxygen and (b) hydrogen around and inside 18-crown-6. The surfaces show the regions where the distribution function, $\mathrm{g}(\mathbf{r})$, is larger than 2 (left), 4 (center) and 8 (right), respectively. The structure of 18-crown-6 was optimized at B3LYP/6-31(d) level.

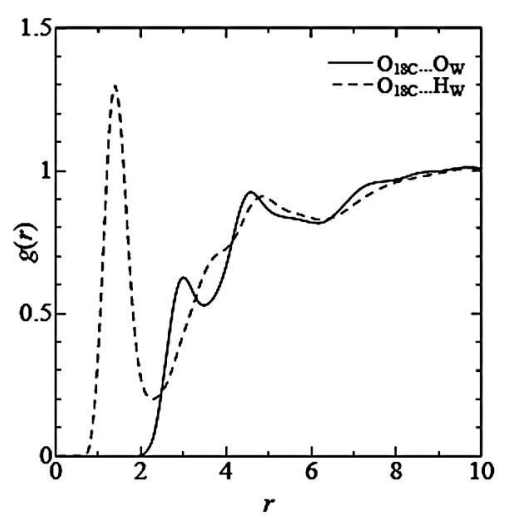

Figure 2. Site-site radial distribution functions between oxygen atom on 18-crown- 6 ether and water oxygen atom (solid line) as well as water hydrogen atom (broken line).

Figure 2 shows radial distribution functions (RDFs): one is the RDF between an oxygen atom on the 18-crown- 6 and the water oxygen as well as the hydrogen, respectively. From 1D-RDFs we can obtain an additional information about the molecular recognition with regard to the distance between the host and the solvent molecules. The site-site distribution functions $g_{\alpha \gamma}^{u v}(r)$ are 
calculated by numerical averaging of the $3 \mathrm{D}$ site distributions $g_{\gamma}^{u v}(\mathbf{r})$ over the solute orientation,

$$
g_{\alpha \gamma}^{u v}(r)=\frac{1}{4 \pi} \int \mathrm{d} \Omega_{\mathbf{r}} g_{\gamma}^{u v}\left(\mathbf{r}_{\alpha}+\mathbf{r}\right)
$$

where $\mathbf{r}_{\alpha}$ is the position of solute site $\alpha$. We calculated the integral over sphere in equation (5) by employing the 700-point set of the repulsion scheme within the quadrature method of spherical harmonic reductions or elimination by a weighted distribution (SHREWD), elaborated by Eden and Levitte [28]. A well-defined peak located around $1.5 \AA$ in the H(water)-O(18-crown-6) RDF shows that a hydrogen bond is formed between the host molecule and the guest molecules. Although the peak around $1.5 \AA$ is contributed from water molecules both inside and outside the cavity (see the left and the center pictures in figure 1), the contributions from the inside of the cavity are much larger than from the outside: hydrogen distribution is hardly seen outside the cavity for the rigid threshold value $(g(\mathbf{r})=8)$.

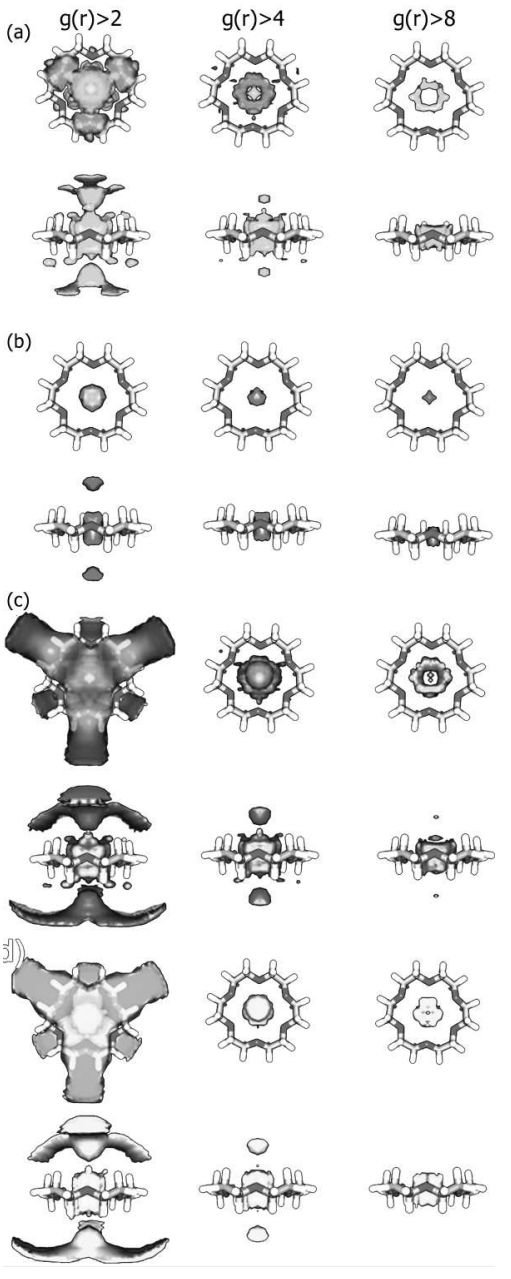

Figure 3. Isosurface representation of the three-dimensional distribution function of cations around and inside 18-crown-6. The surfaces show the regions where the distribution function, $\mathrm{g}(\mathbf{r})$, is larger than 2 (left), 4 (center) and 8 (right), respectively. The structure of 18-crown-6 was optimized at B3LYP/6-31(d) level. (a) Lithium cation. (b) Potassium cation. (c) Magnesium cation. (d) Calcium cation.
The 3D distributions $g(\mathbf{r})$ of each cation around 18-crown-6 are shown in figure 3 : the threshold values are 2, 4 and 8 from the left to the right, respectively. In figure $3(\mathrm{a}), g(\mathbf{r})$ for $\mathrm{Li}^{+}$ around the ether, colored by green, shows $\mathrm{Li}^{+}$ distributes to form a ring-like shape inside the cavity. This picture shows a shift of the position of $\mathrm{Li}^{+}$from the center of cavity. Note that the size of $\mathrm{Li}^{+}$is smaller than that of cavity. In general, it is difficult to obtain an X-ray structure of lithium due to its small atomic number. Therefore, the accuracy of the calculation results in comparison with the experimental data is still unknown. Figure 3(b) shows $g(\mathbf{r})$ of $\mathrm{K}^{+}$around 18-crown-6, which is colored by purple. The highest peak is seen in the center of the ring, although $g(\mathbf{r})$ of $\mathrm{Li}^{+}$spreads like a ring shape and is not seen in the center. This result indicates that 18 -crown- 6 accommodates $\mathrm{K}^{+}$, whereas 12 crown-6 does not recognize $\mathrm{K}^{+}$. $\mathrm{K}^{+}$locates at the center of the cavity because the size of $\mathrm{K}^{+}$is almost the same as that of cavity. The result is consistent with the experimental one: $\mathrm{K}^{+}$has a higher affinity for the 18-crown-6 than any other cation in alkali metals. $g(\mathbf{r})$ of $\mathrm{Mg}^{2+}$ around $18-$ crown- 6 is painted in blue (figures $3(\mathrm{c})$ ). It is found that the blue surface outside the ether is completely different from those of $\mathrm{Li}^{+}$and $\mathrm{K}^{+}$, while the isosurface inside the 18 -crown- 6 is very similar to the $g(\mathbf{r})$ of $\mathrm{Li}^{+}$. This indicates that the electrostatic interaction between oxygen atoms on the 18-crown-6 and $\mathrm{Mg}^{2+}$ is stronger than the mono cation cases. In figure $3(\mathrm{~d})$, the $3 \mathrm{D}$ distribution function of $\mathrm{Ca}^{2+}$ around the crown ether is indicated. Apart from 12-crown-4, the calcium cation is found inside the cavity of 18 crown-6. This result indicates that the size of cavity is large enough to trap a cation with being hydrated even after the entrapment when it approaches the binding-site. The cations are small enough to be accommodated in the host cavity 
and stabilized by the electrostatic potential produced by the surrounding oxygen atoms. Our heuristic approach to the molecular recognition does not need any further calculations. This method has been successfully applied to the molecular recognition between 18-crown- 6 and the cations as in our previous studies [9-11].
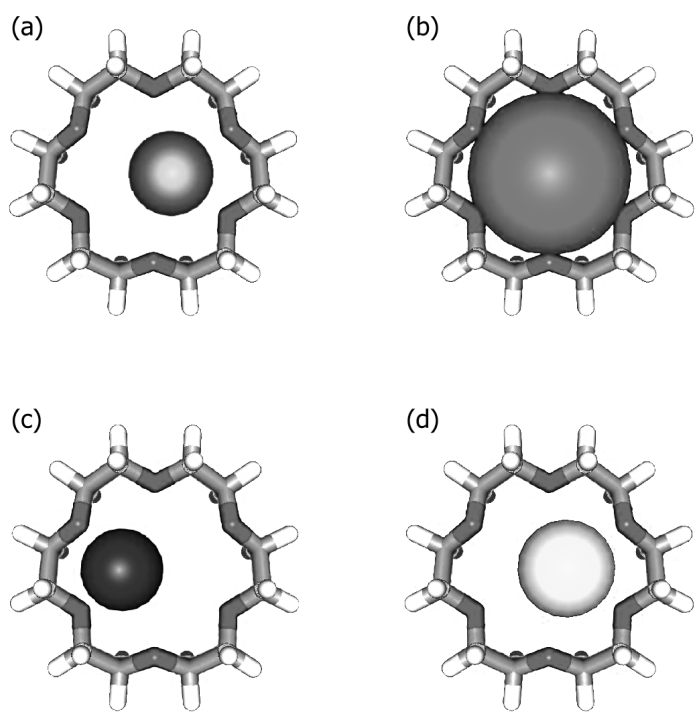

Figure 4. Stable positions of cations inside 18-crown-6. (a) Lithium cation. (b) Potassium cation. (c) Magnesium cation. (d) Calcium cation.

Each cation is located at the most suitable position inside the host's cavity, which is estimated with taking into consideration 3D-DFs (figure 4). Figure 4(b) shows there seems to be no space to hydrate $\mathrm{K}^{+}$and the others in figure 4 show the cavity is not filled by each cation. It is, therefore, necessary to examine whether these trial cations are hydrated or not when they are trapped by the supra-molecule. Converting 3D-DFs to 1D-RDFs gives us hints as to this question. According to the 1D-RDFs around each trapped cation which is explicitly located in the cavity, it is found that there are characteristic peaks of hydrogen bond, except $\mathrm{K}^{+}$(figure 5). This result can be explained from the point of whether the cation size is large enough to fill the cavity or not. Then the recognition process between $\mathrm{K}^{+}$and the host molecule requires the dehydration process before the capture. Once $\mathrm{K}^{+}$is trapped by the host, the host-guest formation would overcome the dehydration penalty. On the other hand, other cations are trapped by 18-crown- 6 without the dehydration process because these naked cations are too small to keep their stability in the cavity. $\mathrm{Mg}^{2+}$ is the typical case of hydration even after the entrapment because the distribution function between the cation and water oxygen represents an intensive peak. Less pronounced peaks are, of course, shown in $\mathrm{Li}^{+}$and $\mathrm{Ca}^{2+}$. Then it is concluded that these cations except $\mathrm{K}^{+}$and the supramolecule could form the host-guest complex without dehydration process. In our previous study on 12-crown-4 ether, the core repulsion between $\mathrm{K}^{+}$and the host molecule was found to be a dominant factor to determine whether $\mathrm{K}^{+}$is recognized or not. Contrary to 12 -crown- 4 , the $\mathrm{K}^{+}$size matches that of the cavity 18 -crown- 6 . The stability of the complex between $\mathrm{K}^{+}$and 18-crown- 6 is more intensive than any other cation because $\mathrm{K}^{+}$is directly trapped by the host molecule without forming hydration structure. As shown in the previous study, $\mathrm{Ca}^{2+}$ is not recognized by 12 - crown- 4 because $\mathrm{Ca}^{2+}$ keeps the hydration structure through all the recognition process. Meanwhile, $\mathrm{Ca}^{2+}$ can be recognized by 18-crown- 6 with being hydrated because the cavity size of this is large enough to accommodate the hydration structure.

Whether solvated structures of cations are kept or not when forming the host-guest complex is determined by the species of each cation. We shall point out that whether hydrated structure is required or not affects the complex stability during such a recognition process. It is an essential information to predict whether a combination of a host molecule and guest molecules is suitable or not, especially when eliminating unnecessary or obstructive components in reaction systems. 


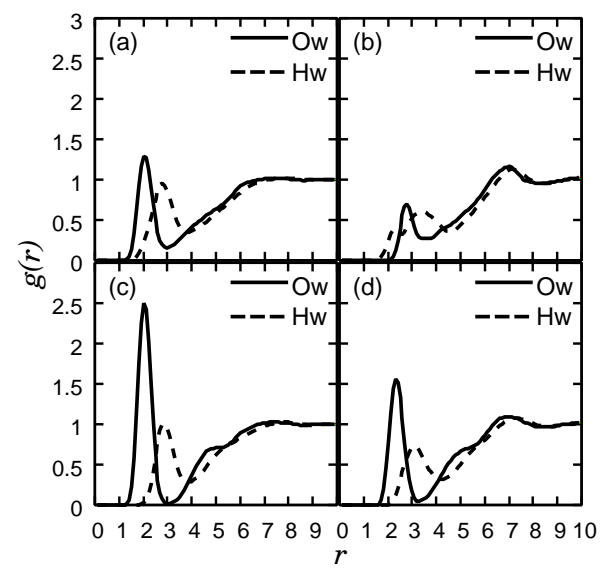

Figure 5. Site-site radial distribution functions between ions and water oxygen atom (solid lines) as well as water hydrogen atom (broken lines). (a) Lithium cation. (b) Potassium cation. (c) Magnesium cation. (d) Calcium cation.

\section{Conclusion}

In this article, we studied the molecular recognition between 18-crown-6 and cations $\left(\mathrm{Li}^{+}\right.$, $\mathrm{K}^{+}, \mathrm{Mg}^{2+}, \mathrm{Ca}^{2+}$ ) by carrying out 3D-RISM calculation. Apart from 12-crown-4, it is difficult to predict the discriminative recognition because the cavity size of the host ether is so large that the hydrated cations are located at the crown center. The results show any cation which was examined in the 3D-RISM study was recognized by an 18-crown- 6 ether. Moreover, 1D-RDF between cations of host-guest complex and solvent water shows that the hydration structure is maintained in the molecular recognition process in the cace of a small size cation, $\mathrm{Mg}^{2+}$. On the other hand, $\mathrm{K}^{+}$is dehydrated in the cavity of an 18-crown-6 ether. Thus, not only cation size but also a hydration/dehydration structure is important for the molecular recognition by crown ether. In this study we carried out the calculations without the flexibility of 18-crown- 6 because of the huge computational cost for the 3DRISM-SCF calculation in electrolyte solution. In the near future, we will report further investigations on this type of molecular recognition including RISM/3DRISMSCF results in progress in our laboratory.

\section{Acknowledgement}

The authors are grateful to the support by the grant from the Next Generation Super Computing Project, Nanoscience Program, MEXT, Japan, and by the grant from Scientific Research on Priority Area of "Water and Biomolecules". The authors thank to Dr. Yoshida for the fruitful discussions and useful information concerning their earlier work.

\section{References}

1. Pedersen, J. C. J. Am. Chem. Soc., 1967, 89, 2495.

2. Pedersen, J. C. J. Am. Chem. Soc., 1967, 89, 7017.

3. Lehn, -M. J., Struct Bond., 1973, 16, 1.

4. Cram, J. D. and Cram, M. J., Acc. Chem. Res., 1978, 11, 8.

5. Atwood, L. J. and Davies, J. "D.D. Mac Nicol Inclusion Compound, vol.3",(Academic Press, New York, 1984)

6. Considering the stability between the $C_{i}$ and the $D_{3 \mathrm{~d}}$ in terms of whether in solution or not, it is found that the $C_{i}$ is more stable by $3 \mathrm{kcal} / \mathrm{mol}$ than the $D_{3 \mathrm{~d}}$ in vacuo (B3LYP/6-31 $+\mathrm{G}(\mathrm{d})$ level of theory) and that the $D_{3 \mathrm{~d}}$ is more stable than the $C_{i}$ in the aqueous on the contrary [7]. This complete reversal for the stability shows the solvent effect may affect the above recognition because the conformation is an essential factor for the recognition. 
7. Gaussian 03, Revision C.02, Frisch, M. J., Trucks, G. W., Schlegel, H. B., Scuseria, G. E., Robb, M. A., Cheeseman, J. R., Montgomery, Jr., J. A., Vreven, T., Kudin, K. N., Burant, J. C., Millam, J. M., Iyengar, S. S., Tomasi, J., Barone, V., Mennucci, B., Cossi, M., Scalmani, G., Rega, N., Petersson, G. A., Nakatsuji, H., Hada, M., Ehara, M., Toyota, K., Fukuda, R., Hasegawa, J., Ishida, M., Nakajima, T., Honda, Y., Kitao, O., Nakai, H., Klene, M., Li, X., Knox, J. E., Hratchian, H. P., Cross, J. B., Bakken, V., Adamo, C., Jaramillo, J., Gomperts, R., Stratmann, R. E., Yazyev, O., Austin, A. J., Cammi, R., Pomelli, C., Ochterski, J. W., Ayala, P. Y., Morokuma, K., Voth, G. A., Salvador, P., Dannenberg, J. J., Zakrzewski, V. G., Dapprich, S., Daniels, A. D., Strain, M. C., Farkas, O., Malick, D. K., Rabuck, A. D., Raghavachari, K., Foresman, J. B., Ortiz, J. V., Cui, Q., Baboul, A. G., Clifford, S., Cioslowski, J., Stefanov, B. B., Liu, G., Liashenko, A., Pisko rz, P., Komaromi, I., Martin, R. L., Fox, D. J., Keith, T., Al-Laham, M. A., Peng, C. Y., Nanayakkara, A., Challacombe, M., Gill, P. M. W., Johnson, B., Chen, W., Wong, M. W., Gonzalez, C., and Pople, J. A., Gaussian, Inc., Wallingford $\mathrm{CT}, 2004$.

8. Hirata, F (Ed.), Molecular Theory of Solvation, Kluwer Academic, 2003.

9. Imai, T., Hiraoka, R., Kovalenko, A., Hirata, F. J.Am. Chem. Soc. Commun., 2005, 127, 15335.

10. Yoshida, N, Phongphanphanee, S., Maruyama, Y., Imai, T., Hirata, F., J. Am. Chem. Soc. Commun., 2006, 128, 12043.

11. Ikuta, Y., Maruyama, Y., Matsugami, M., Hirata, F., Chem. Phys. Lett., 2007, 433, 403.

12. Ha, L. Y., Charkrabory, K. A., J. Phys. Chem., 1994, 98, 11193.

13. Schmidt, F. K., Kast, M. S., J. Phys. Chem. B, 2002, 106, 6289.

14. Kinoshita, M., Okamoto, Y., Hirata, F., J. Am. Chem. Soc., 1998, 120, 1855.

15. Beglov, D., Roux,B., J. Phys. Chem., 1997, B 101, 7821.

16. Kovalenko, A., Hirata, F., Chem. Phys. Lett., 1998, 290, 237.

17. Kovalenko, A., Hirata, F., J. Chem. Phys., 1999, 110, 10095.

18. Kovalenko, A., Hirata, F., J. Chem. Phys., 2000, 112, 10391.

19. J. S. Perkyns, S. J., Pettitt,B. M., Chem. Phys. Lett., 1992, 190, 626.

20. J. S. Perkyns, S. J., Pettitt,B. M., J. Chem. Phys., 1992, 97, 7656.

21. Kovalenko, A., Hirata, F., J. Chem. Phys., 2000, 112, 10403.

22. Kovalenko, A., Hirata, F., Chem. Phys. Lett., 2001, 349, 496.

23. Kovalenko, A., Hirata, F., J. Phys. Chem., 1999, B 103, 7942.

24. Kahn K., Bruice T. C., J. Comput. Chem., 2002, 23, 977.

25. Berndsen, C. J. H., Grigera, R. H., Straatsma, P. T., J. Phys. Chem., 1987, 91, 6269

26. Jorgensen W. L., Maxwell D. S., Tirado-Rives J., J. Am. Chem. Soc., 1996, 118, 11225.

27. Kovalenko, A., Ten-no, S., Hirata, F., J. Comput. Chem., 1999, 20, 928.

28. Ede'n, M., Levitt, H. M., J. Magn. Reson., 1998, 132, 200.

\title{
Дослідження теорією 3D-RISM катіонів, впізнаваних ефірною короною: II 18-корона-6 ефір
}

\author{
Ю.Маруяма ${ }^{1}$, М.Матсугамі ${ }^{2}$ Я.Ікута ${ }^{1}$ \\ 1 Факультет теоретичних досліджень, Інститут молекулярних наук, Оказакі,Аічі, Японія \\ 2 Хімія, Загальна освіта, Національний технологічний коледж в Кумоното, Суя, Коші, Кумоното, Японія
}

Отримано 4 червня 2007 р., 18 липня 2007 р.

В попередніх дослідженнях ми вивчали в рамках теорії 3D-RISM катіонне впізнавання 12-корона-4 ефіром [lkuta, Y. et al., Chem. Phys. Lett., 2007, 433, 403] і показали застосованість цієї теорії. Результати показують, що 12-корона-4 ефір впізнає іони $\mathrm{Li}^{+}$і $\mathrm{Mg}^{2+}$. 18-корона-6 ефір ширше використовується порівняно 3 12-корона-4 ефіром. В даній роботі розраховано тривимірні функції розподілу води відносно іонів $\mathrm{Li}^{+}, \mathrm{K}^{+}, \mathrm{Mg}^{2+}, \mathrm{Ca}^{2+}$ в середині та зовні 18-корона-6 ефіру у водних розчинах електроліту. Показано, що 18-корона-6 ефір впізнає не тільки іони $\mathrm{Li}^{+} \mathrm{i} \mathrm{Mg}^{2+}$, але також іони $\mathrm{K}^{+} \mathrm{i}$ $\mathrm{Ca}^{2+} . \mathrm{K}^{+}$всередині порожнини дегідратується, тоді як інші катіони є гідратованими. Встановлено, що гідратаційна структура та катіонні розміри є важливими для молекулярного впізнавання коронним ефіром.

Ключові слова: 3D-RISM, теорія, молекулярне впізнавання, коронний ефір, катіон

PACS: $02.30 . R z, 31.15 . B s, 61.25 . E m$ 